$\begin{gathered}\text { EPiC Series in Education Science } \\ \text { Volume 2, 2019, Pages 18-27 } \\ \text { Proceedings of Learning Innova- } \\ \text { tions and Quality (LINQ) 2019 }\end{gathered}$
$\begin{gathered}\text { EPiC } \\ \text { Education } \\ \text { Science }\end{gathered}$

\title{
Extending openness in education support services for out-of-school children in underprivileged circumstances
}

\author{
Faisal Bin Badar \\ Charles Darwin University, Darwin, Australia. \\ faisal.badarestudents.cdu.edu.au
}

\begin{abstract}
Openness has underpinned much of the evolution of the Internet and digital technologies that support learning. Worldwide, openness in education has provided access to high-quality learning opportunities for school-age learners during the last two decades. During this same era, several global initiatives have made it their mission to educate all children of the world. However, despite major technological advancements in education and new innovative learning solutions, efforts to reduce large numbers of outof-school children do not show promising outcomes in many parts of the world, let alone quality outcomes. This paper analyses the importance of context for educational outcomes and examines the need to understand socio-cultural and economic limiting factors of out-of-school children in underprivileged contexts in Pakistan. In such contexts, development demands sustainable and adaptable solutions. In identifying possible 'solutions', innovative strategies to educate out-of-school children is explored through combining traditional one-room schoolhouse methods with innovative digital technology and Open Education Resources to provide learning opportunities suited to their needs.
\end{abstract}

\section{Introduction}

Context is a fundamental factor in determining educational outcomes. In this paper, the primary contextual concern is out-of-school children (OOSC) living in underprivileged settings in Pakistan. This is the contextual and cultural setting. Additionally, there is context that relates to three key drivers of change: (1) the evolution of digital technology capabilities; (2) the evolution of information and communications technology (ICT); and (3) the evolution of the 'open agenda' in education (Leeson \& Mason, 2007; Mason \& Pillay, 2015). In considering the dynamics involved, this paper presents an analysis of the state-of-play in terms of 'global' interventions aimed at solving problems of educational opportunity for the disadvantaged and explores options involving a combination of traditional schooling 
methods (such as the one-room multi-grade schoolhouse), stakeholder needs that are specific to local conditions, innovations in digital technology and application of open educational resources.

\section{Opening digital learning horizons in school education}

The ubiquitous use of digital technology globally has revolutionised the processes and practices in almost every field, and education is no exception. Continued innovations in the use of technology in education during the last two decades is driven by diversified opportunities emerging in practice and research domains (Mason \& Pillay, 2015). Digital learning technologies provides pathway to openness in education in terms of access and quality.

\subsection{Digital learning revolution}

Digital learning is a contemporary term which arguably represents a broader spectrum for all kinds of technologies utilised in learning and encompasses many similar terms in use such as e-learning, online learning, mobile learning etc. However, significant research literature is still linked to a widely accepted term e-learning. Sangra (2012) identified four broad categories of e-learning: technology driven, delivery-system centered, communication oriented, and educational paradigm focused. A major shift in e-learning theory and practice is experienced at the beginning of this decade through the ubiquitous use of mobile technology, where the hand-held devices based so-called natural user interface (NUI) gradually cannibalised the personal computer-based windows-icon-mouse-pointer (WIMP) paradigm (Oller, 2012). The emergence of data-intensive science and research in digital arena is likely to bring advancement in digital learning context also, as presently being experienced by other industries (Knight, 2017).

\subsection{Openness in education}

The word open has high utility involving a broad range of semantics, as evidenced in the latest edition of Australian Macquarie Dictionary where over 80 meanings listed. However, the diversified set of semantics related to this word also hinders achieving the collective acceptability of its meanings within research and other usage. In social, digital learning and educational research contexts, the word open is associated with many terms, such as open education, open source software, open learning, open license, open access, open courseware (OCW), open standards, open universities, open architecture, open knowledge initiative (OKI), open content, open scholarship, open educational resources (OER), open educational practices (OEP), open government, open teaching, Massive online open courses (MOOC), open data, and open digital learning etc. An analysis of usage of term openness in digital era reveals that this term is predominantly used for the themes associated with access, intellectual property, benefit to the public domain, sharing, and technical interoperability (Mason \& Pillay, 2015). However, there are exceptions to usage of this term beyond these themes such as open learning, a term attributed to Montessori (1967/1949) which refers to independent, inquiry-based, and self-determined learning (Dewey, 1910; Piaget, 1966; Brugelmann, 1975; Lillard, 2005).

With the emergence of technological advancements in education, there is an ongoing fear among teachers assuming significant reduction in their roles in digital learning environment. Conversely, Trucano (2015) mentions, “...teachers' roles become more central, and not peripheral as a result of the introduction of new technologies. The teachers who do not use technology will be replaced with those who do". In fact, there is an acute shortage of teacher and the world needs around 69 million teachers to reach 2030 SDG-4 educational goal (UIS 2016). However, the role of teachers will eventually shift from routine administrative tasks to building 21 st century skills such as problem-solving, critical thinking, cross-cultural communication etc. in their students. 


\section{Global efforts and a 100-Year gap}

Educational stakeholders have globally ventured several initiatives to implement contemporary educational ideas, methods and technologies, with promising agendas focusing towards $21^{\text {st }}$ century skills to overcome the emerging global challenges to educate out-of-school children (OOSC). 'Education for All' (EFA) was initiated by UNESCO in 2000 to provide primary education to all children by 2015, and Millennium Development Goals (MGD) were set by UNDP, UNESCO, UNICEF and the World Bank to help reduce uneducated youth (UNESCO, 2007). Sustainable Development Goals (SDG) were set by UN to achieve targets in 17 world major issues, and SDG-4 targets education for all children of the world by 2030 .

\subsection{Out-of-school children (OOSC)}

There are 263 million children, adolescents, and youth out of school. Despite all the global initiatives, one out of every five children, adolescents, and youth globally are out-of-school, and the progress to educate them in recent years has declined further (UIS, 2018). According to (UIS, 2019), "Three years after the adoption of Sustainable Development Goal 4 (SDG 4) and the promise to provide universal primary and secondary education, there has been no progress in reducing the global number of out-of-school children, adolescents and youth".

\subsection{The 100-Year gap}

There is a deep disproportion among and within countries regarding the learning process for their school-age population in terms of what they learn, know and do. Millions for children globally are unable to reach the school doors, and another vast majority is among those dropouts who do not make it till the end of the school years or unable to acquire the learning skills and capacities expected from them during these school years. Most of these sufferings are from the poorest backgrounds of the world and the worst impact is that these underprivileged children need another 100 years to catch up with their counterparts (Winthrop \& McGivney, 2015).

\subsection{Need to bridge the gap for Out-of-School Children}

With a consistent figure of around 263 million children, adolescents and youth between ages 6 and 17 years are out-of-school throughout the decade, it is evident that the global efforts are not yielding any progressive results. The pace at which change is happening is unlikely to overcome the skill deficiency among this underprivileged segment of world population in many decades to come and may take approximately a hundred years for these OOSC to reach today's education levels of rich children of the world (Winthrop \& McGivney, 2015). We need to re-think ways to educate these underprivileged masses (Badar, Mason, Khan, 2018).

The Education Commission has projected that by 2030 more than half of the world's 2 billion children will not be able to acquire their basic secondary level learning skills, and approximately 9 out of 10 children from low-income countries are anticipated to reach their adulthood without the skills they need to progress (The Learning Generation, 2016). Program for International Student Assessment (PISA) examinations present a 57\% gap in secondary mathematics proficiency between rich and poor students. In Morocco, only 24\% low and middle-income students meet basic mathematics benchmark (Murnane, 2011), and in Latin America, nearly half of the boys drop-out of secondary school, partly due to lack of quality education (Rogers, 2016). 


\subsection{Impact of not educating OOSCs on global economy}

The long-term effect of depriving these children from getting education is that this segment of global population lack basic professional skills to contribute optimally in global economy. During the industrial economy era, education was considered an input to the production process and out-of-school children could be absorbed by the society through social welfare systems or by employing them at a low-level job. However, digital revolution and the knowledge economy is likely to affect the low-level jobs most, and these out-of-school children will be unable to become as productive anymore for the global economy. Moreover, in the knowledge economy, education is not an input to the production process, but a resource itself, and learning process has gained more importance than the attainment of structured qualifications. By leaving these out-of-school children behind, the global community is getting deprived of their untapped novel ideas, their innovations, their networking skills, their creative problem-solving approaches, their communication patterns and logics. In macroeconomic context, the world is leaving a considerable portion of the available brain power un-utilised. As most of the lowand middle-income countries possess these out-of-school children, these children become counterproductive for national economic progress and growth of these countries (Ilon, 2017).

\section{Importance of context for educational outcomes}

Almost half of the world's population is under the age of 20 years, and most of them are from developing countries (Commonwealth Secretariat, 2016). In terms of OOSCs, most of the children without access to the schools are girls from developing countries (World Literacy Forum, 2012). There are several factors which differentiate school education in developing countries with that of developed countries, and the challenges of school education in developing countries cannot be analysed without deep understanding the underpinning socio-cultural and economic factors for these OOSCs in underprivileged context.

One solution may not be applicable in diverse contexts as some strategies that worked for any specific time and space, using any set of resources including teachers, and in a particular context may not yield desired outcomes in another scenario. Context plays a very important role in the success of using digital technologies in education (Lucking, 2012). Fullan and Langworthy (2013) mention that effective educational outcomes can be achieved by developing strategies considering the context in which they will be applied. A careful analysis of the underpinning factors leading to success of certain technology-based initiatives and failures of other highly funded global digital technology-based innovations may become an initial step towards building a sustainable solution for OOSCs. These lessons from history can also show us an effective roadmap to approach the immense and uncontrolled problem of bringing back the OOSCs to the education stream. Studies show that many technologybased educational imported solutions for OOSCs developed in developed countries could not deliver expected outcomes in underprivileged contexts despite global support and enormous funding for these projects due to lack of awareness of ground realities and limiting contextual factors (Badar et al., 2018).

\subsection{Pakistan - Education, economy and demographics}

The educational grading structures in Pakistan comprises pre-primary, primary, middle (also known as lower secondary), secondary, higher secondary and higher education (university) level. Ages of preprimary school children are between 3 to 5 years; children in primary classes (1-5) are of ages 6 to 10 years; Middle classes (6-8) children are of ages 11 to 13 years; whereas secondary classes (9-10) have children of ages 14 to 16 years. Socioeconomic status (SES) of the family presents its social and economic position in the society. Education of parents, their income and occupation determine the socioeconomic class (SEC) of any family and considered the decisive factors for attaining the level of 
respect in the society (Ghazi, 2013). At national poverty line, the poverty headcount ratio is 24.3 (World Bank, 2018), which creates difficulties to the people in extreme poverty to survive. $62 \%$ of Pakistan's population lives in the rural areas and $60 \%$ of the population depend on agriculture. The quality and standard of education in rural areas are going down, and thus increasing urban/rural disparities and inequalities in Pakistan, which is creating the learning crisis in low-income rural areas (Agarwal, 2014). The funds granted by the international funding agencies are not being utilized effectively and hence there the education sector in Pakistan is badly affected in last few decades (Khan, 2016).

\subsection{Pakistan - Education and Out-of-School Children Status}

Education plays an important role in building foundations of any country. Pakistan is the fifth most populated country in the world (US Census Bureau, 2019), with 63\% population under the age of 25 years (PBS, 2016). Globally, it has the third highest rate of out-of-school children, adolescents and youth of primary and secondary school age population in the world (UIS, 2018). Pakistan has also been a signatory participant of the World Conference on Education for All, 1990; Dakar World Education Forum 2000; Millennium Goals, 2000 and the UN Convention on Rights of the Child, 1989. However, according to the EFA Global Monitoring Report 2015, progress made by Pakistan in terms of reducing out-of-school population is far less than expected, partly due to ethnic and religious frictions, corrupt political leadership and weak democracy (UNESCO, 2015). The newly elected government in Pakistan brings much hope to the Pakistani community for adapting innovative approaches towards education. The newly elected Prime Minister Imran Khan, an Oxford graduate and former leading Cricket superstar, along with highly qualified and experienced team is expected to take major decisions in education to overcome the negligence in this segment by previous governments.

\section{Developing sustainable learning strategies}

To develop quality adaptable and sustainable solutions to educate OOSCs in underprivileged contexts in developing countries, a more viable option may be to, as a foremost step, study their local socio-cultural and financial limitation and the dominating factors stopping these children from their learning process. The next effective step may be to explore the means available within these communities such as locally administered one-room multi-grade schoolhouses, and then finally, develop an integrated approach to blend the available means with technology, built around a conducive learning environment suited to their circumstances. These local understandings can be developed through number of research tools including, but not limited to, surveys, interviews and focus groups, or observations with the direct and indirect stakeholders of OOSCs. The above-mentioned sequential approach may also bring inclusion and ownership from the community for the initiative instead of developing their feeling of alienation and isolation due to their perception of an imported solution being imposed on them.

Discussion on efficacy of one-room schoolhouses, digital learning, and Open Educational Resources (OERs), and the possibility of integrating the traditional and contemporary educational techniques for OOSCs in underprivileged context in Pakistan is covered in subsequent sub-sections.

\subsection{One-room schoolhouses - an effective traditional learning model}

During the last three centuries, traditional one-room schoolhouses all over the world have played an important role in shaping the history of education (Williams, 2005). These schools adopted the means for an integrated approach to the curriculum, often mixing age and aptitude. This traditional method can be investigated for $21^{\text {st }}$ century options to educate OOSCs, as it offers room to accommodate 
technological advancements through integrated approaches. Research indicates that non-cognitive learning abilities of the students improve in a multi-age peer-learning environment, giving them opportunity to mentor relatively less advanced students in that domain (Cundra, Benzel, \& Schwebach, 2017). Pakistan has number of one-room schoolhouses in remote and rural areas to provide optimal learning to OOSCs, being operated by various Not-for-Profit organisation. These schools can be equipped through technology to provide quality education to OOSCs coming to these schools and to overcome their challenges of attracting quality teachers in these remote locations.

One of the prominent chains of one-room schoolhouse in rural Pakistan is Raunaq-e-Islam Neighbourhood Schools (RINHS) that utilises centuries old one-room schoolhouse practices to educate the rural and remote communities in a blended learning environment. RINHS are multi-grade one-room schoolhouses in rural Pakistan operated by the Pakistan Memon Women Educational Society (PMWES) and serving out-of-school children in underprivileged communities since 2010. Demographically, RINH Schools are operating in rural and low-socio economic areas of Karachi with limited access to educational institutions. Government schools in these areas are in pathetic condition where school infrastructure (classrooms, drinking water and toilets) is very poor. Most households in these areas live below the poverty line and cannot afford to send their children to the private schools in the vicinity. Moreover, cultural and traditional norms also restrict transportation of female students to far-away areas for educational purposes. RINH Schools represent an alternative learning environment with suitable hygienic conditions for students not going to schools elsewhere. Students are taught in a multi-grade environment with considerable range of age cohorts within one classroom. Instructions in these classrooms follow weekly plans developed by RINHS academic team using government curriculum and books. However, extra-curricular activities are also regularly conducted to develop these students' cognitive, non-cognitive and social skills and abilities. Teachers dedicate their time and efforts with an aim to bring their students beyond the curricular goals and to develop them as responsible and independently learners. The learning atmosphere in these schools is also designed and implemented keeping the local socio-cultural context. The parents are happy with the dedication and efforts of the teachers and the efficacy of the multi-grade classrooms, which are also successful in integrating children with varied capacities and needs.

\subsection{Digital learning and its contribution for OOSCs}

Open education and digital learning provide an attractive learning option for out-of-school children, which allows them to learn at their own pace, at their chosen location and time (Clark \& Mayer, 2011). E-learning environment provides learning experience which is considerably more flexibility to the learners as compared to the traditional learning system and is economically feasible for the educators and learners (Stericker, 2013). Open and distance learning environments also provide flexibility in course selection and assessments which is otherwise not available in conventional educational systems (Singh, 2012).

Education in developing countries, particularly in OOSC context, could be transformed by and benefit from e-learning through effective and innovative application of digital technology (Badar et al., 2018). Contemporary digital technology approaches such as online learning, Open Educational Resources (OERs), Massive Open Online Courses (MOOCs) and Learning Management Systems (LMS) such as Moodle have transformed learning environments and improved students' satisfaction (Ali, 2011). The ubiquitous use of mobile technology in developing countries has opened new avenues to innovative educational opportunities, access, and quality for out-of-school children. We need to integrate digital technologies and learning objectives to explore the new horizons of teaching and learning for developing countries. To tackle educational challenges, systemic integration of ICT has been outlined as an opportunity for improving the quality of teaching and learning as well as expanding access to learning opportunities (UNESCO, 2011). Where the main reasons behind out-of-school 
secondary level children are poverty, location, and gender (EFA, 2011), learning models based on mobile technology can provide access to "people who live in a remote location where there are no schools, teachers and libraries" (Ally, 2009). "The implications of literacy increase through the transition away from only voice and SMS phones towards more sophisticated smart phones, where educational content can be accessed and learning achieved"(Grimus,2013). M-learning provides the learner the leverage to decide what, when, where, why and how to learn, making it an individualized, personalized and highly interactive learning (Cobcroft, 2006). Mobile phones are widely considered as the optimal solution for delivering education in developing countries, because of their usability, accessibility, and affordability (Grimus, 2013; Ford \& Leinonen, 2009).

RINHS has successfully penetrated the isolated communities in rural and remote areas around Karachi region through their one-room schoolhouse educational model, which develops the schools and teachers from within the deprived communities. The model offers sense of security to these communities as their own community member/s, who are trained by RINHS teachers training team, teach the children. However, quality of teachers is the weakest link in RINHS multi-grade one-room learning system. As these schools are in far-away remote areas, good quality teachers from urban areas do not prefer to join these schools. The locally trained teachers have limitation in term of their educational backgrounds, exposure to latest teaching techniques and technology related educational developments. To overcome the lack in teaching quality issue, RINHS is developing education technology based-learning system for these neighbourhood schools. The purpose of this initiative was to provide global level education to these deprived children through local medium through digital transformation of RINHS according to the $21^{\text {st }}$ learning techniques, hence satisfying the quality education needs without crossing community's cultural limitations.

\subsection{Review of impact of OERs in underprivileged context}

The term Open Educational Resource was first introduced in UNESCO's Forum on Open Courseware in 2002 (Wiley \& Duval, 2010). Tuomi (2013) defined OER as "teaching, learning and research resources that reside in the public domain or have been released under an intellectual property license that permits their free use or re-purposing by others". The defined role of OER promotes the existing declarations and guidelines, learning possibilities and technology including 2007 Cape Town Open Education Declaration, the 2009 Dakar Declaration on OER, the 2011 Commonwealth of Learning and UNESCO Guidelines on OERs in Higher Education, and 2012 Paris Declaration which recommends to the states (Cobo, 2013, Zancanaro et al., 2015). The UNESCO OER community comprising over 100 member states, identifies the educators, teacher trainers, librarians, learners, parents, education policy makes at governmental and institutional levels, teachers and others as the stakeholders for the active use of OER to promote educational benefits to all children of the world through building the capacity of users to create and share OER, managing language and cultural issues, ensuring equitable and inclusive access to quality OER, developing sustainable models, and developing supportive policy environment (UNESCO, 2019).

An external evaluation of the impact of UNESCO OER highlighted that the efforts have yielded in building awareness, capacity and policies to support OER at country and organisational levels with varied success levels of different strategies adopted (ORS Evaluation, 2015). It further mentions that the use of OER has increased and diversified steadily at all avenues of international work on OER since the 2012 Paris OER Declaration; however, it is not documented in a systematic way and has not created a significant impact, particularly at a policy level. "The movement has not yet developed to that stage. In the short term, there is still an important role for external organizations to play, including providing tangible examples and models of policies, supporting policy implementation, and promoting the development of linguistically-and-culturally relevant OER content...” (ORS Evaluation, 2015). 


\section{Conclusion}

Digital technologies and openness in education have revolutionised learning environments globally during the last two decades. At the same time, global organisations are still struggling to educate a large segment of society i.e. the out-of-school children of the world in underprivileged context. Despite extensive global efforts, there is not much significant outcome in reducing these out-of-school children in many parts of the world. There is a need to re-think ways to educate these disadvantaged children and educational benefits of the digital and 'open' learning revolution can become an opportunity to develop appropriate approaches to educate these children.

Traditional educational methods such as one-room multi-grade schoolhouses have already set their footprints in rural and remote areas of Pakistan through the initiatives of many local visionaries and other organisations striving to educate children in these locations. However, due to the inherent limitation in their learning model, these learning platforms lack quality in education delivery and expandability for the children still not coming to these schools. The contemporary evolution of digital technology capabilities, evolution of Information and Communication Technologies, and evolution of open agenda in education, if integrated with well-established traditional alternate education methods like one-room schoolhouses can bring promising outcomes to bring sustainable and adaptable learning solution for the out-of-school children in underprivileged circumstances, suited to their local context.

\section{References}

Agrawal, T. (2014). Educational Inequality In Rural And Urban India. International Journal Of Educational Development, Vol. 34, (pp.11-19).

Ali, A. (2011). Key factors for determining students' satisfaction in distance learning courses. A study of Allama Iqbal Open University. Turkish Online journal of Distance Education. Vol.12(2) (pp.114127).

Ally, M. (Ed.). (2009). Mobile learning: Transforming the delivery of education and training. Athabasca University Press.

Badar, F., Mason, J., \& Khan, K. (2018). Re-thinking out-of-school learning in rural Pakistan. Proceedings of the 26th International Conference on Computers in Education. Philippines: AsiaPacific Society for Computers in Education. (pp. 440-445).

Brugelmann, Y. (1975). Open Curricula-A paradox? Cambridge Journal of Education, Vol. 1(5), (pp.12-20).

Clark, R. C., \& Mayer, R. E. (2011). E-Learning and the Science of Instruction: Proven Guidelines for Consumers and Designers of Multimedia Learning. New Jersey: John Wiley \& Sons.

Cobcraft, R., Towers, S., Smith, J., \& Bruns, A. (2006). Mobile learning in review: Opportunities and challenges for. Proceedings. Online Learning and Teaching (OLT) Conference (pp. 21-30). Brisbane: Queensland University of Technology.

Cobo, C. (2013). Exploration of Open Educational Resources in Non-English Speaking Communities. The International Review of Research in Open and Distributed Learning, Vol. 14(2), (pp.106-128).

Commonwealth Secretariat (2016). Global Youth Development Index and Report. Westminister: Commonwealth Secretariat.

Dewey, J. (1910). How we think: Restatement of the relation of reflective thinking to the educative process. Republished edition, 2008. Now York, NY: Cosimo Books.

Education Commission (2016). The Learning Generation: Investing in education for a changing world. The International Commision on financing global education opportunity.

Ford, M., \& Leinonen, T. (2009). MobilED: a mobile tools and services platform for formal and informal learning. 5th World Conference on Mobile Learning. Banff. 
Fullan, M., \& Langworthy, M. (2013). Towards a new end: New pedagogies for deep learning. Seattle Washington: Collaborative impact.

Ghazi, S. R., Nawaz, K., Shahzad, S., Shahzada, G., \& Rukhsar, M. (2013). Relationship Between Parents' Socio-economic Status And Their Children Academic Performance. International Review Of Social Sciences And Humanities, Vol.5(2), (pp.58-65).

Grimus, M., Ebner, M., \& Holzinger, A. (2013). Mobile Learning as a Chance to Enhance Education in Developing Countries-on the Example of Ghana. CEUR Workshop Proceedings, 955, (pp. 340345). Helsinki.

Ilon. (2017). The cost of not educating the world's poor: the new economics of learning. New York, NY: Routledge.

Khan, S., Lurhathaiopat, P., \& Matsushita, S. (2016). The Contribution of international community and the dynamics of history in educational policies in Pakistan: The case of success or failure. International Journal Of Current Research, Vol.8(2), (pp.42150-42156).

Knight, S., \& Buckingham Sham, S. (2017). Theory and Learning Analytics. On C. Lang, G. Siemens, A. Wise, \& D. Gasevic (Eds), The Handbook of Learning Analytics: Society for Learning Analytics Research.

Laurillard, D. (2008). Open teaching: The key to sustainable and effective open education. In Toru Liyoshi \& M. S. Vijay Kumar (Eds.), Opening up education: The collective advancement of education through open technology, open content, and open knowledge. Cambridge, MA: MIT Press.

Leeson, J. \& Mason, J. (2007). The Open Agenda and Organisational Alignment, Supplementary Proceedings, The $15^{\text {th }}$ International Conference on Computers in Education, Vol 1, (pp. 189-194).

Lucking, R., Bligh, B., Munches, A., Ainsworth, S., \& Noss, R. (2012). Decoding learning: The proof, promise and potential of digital education. London: Nesta.

Mason, J., \& Pillay, H. (2015). Opening Digital Learning to Deeper Inquiry. In Mohammad Ally \& Badrul Khan (Eds.). The International Handbook of E-learning, Vol 2, Implementation and CaseStudies. (pp. 1-10). New York, NY: Routledge.

Murnane, R. J., \& Duncan, G. J., (2011). Whither opportunity? Rising Inequality, School, and Children's life Chances. Russell Sage Foundation. New York.

OER Impact, Evaluation of th eWilliam and Flora Hewlett Foundation's Investment in International Policy Advocacy for Open Education resources, June 2015.

Oller, R. (2012). The future of Mobile Learning. EDUCAUSE Center for Applied Research.

Pakistan Bureau of Statistics, (2015). Pakistan social and living standards for individuals aged 15 and above. Karachi: Pakistan Bureau of Statistics

Piaget, J. (1966). The child's conception of physical causality. London, UK: Routledge and Kegan Paul.

Sangra, A., Vlachopuolulos, D., \& Cabrera, N. (2012). Building an inclusive definition of e-learning: An approach to the conceptual framework. International Review of Research in Open and Distance Learning, Vol. 13 (2), (pp.145-159).

Rogers, H. (2016). The 'Nini' youth of Latin America: Out of School, Out of Work, and Misunderstood. World Bank.

Singh, S., Singh, A., \& Singh, K. (2012). Motivation Levels Among Traditional and Open Learning Undergraduate Students in India. International Review of Research in Open and Distance Learning, Vol. 13(3).

Stericker, J. (2013) The Importance of eLearning in Learning and Development Models. Presented at the Corporate \& Government Learning Congress: EduTECH 2013. Brisbane Convention and Exhibition Centre, (pp. 3-5).

Trucano. (2015). Will technology replace teachers? No, but..... World bank Blogs, 24 Feb 2015. Retrieved from https://blogs.worldbank.org/edutech/tech-and-teachers 
Tuomi, I. (2013). Open Educational Resources and the Transformation of Education. European Journal of Education, Vol. 48(1), (pp. 58-78).

UNESCO. (2007). A framework for the realization of children's right to education and rights within education. A Human Rights-Based Approach to EDUCATION FOR ALL

UNESCO. (2011). Global Monitoring Report 2011: Regional overview: Sub-Saharan Africa: The hidden crises: Armed conflict and education.

UNESCO. (2015). Global Monitoring Report 2015: Education for All 2000-2015: Achievements and Challenges.

UNESCO Institute of Statistics, (2018). Rate of out-of-school children, adolescents and youth of primary and secondary school age in Pakistan. Retrieved from http://data.uis.unesco.org/index.aspx?queryid=121

UNESCO. (2019). Open Educational Resources. Retrieved from https://en.unesco.org/themes/building-knowledge-societies/oer.

UNESCO Institute of Statistics (UIS), (2016, October). 2016. UIS Fact Sheet No. 39 (UIS/FS/2016/ED/39).

UNESCO Institute of Statistics (UIS), (2018, February). 2018. UIS Fact Sheet No. 48 (UIS/FS/2018/ED/48).

UNESCO Institute of Statistics (UIS), (2019, September). 2019. UIS Fact Sheet No. 56 (UIS/FS/2019/ED/56).

US Census Bureau, (2019, July 01). US Census Bureau Database: Largest populated countries of the world. Retrieved from https://www.census.gov/popclock/.

Wiley, D. \& Duval, E. (2010). Guest Editorial: Open Educational Resources. Learning Technologies, IEEE Transactions Vol. 3(2), (pp. 83- 84).

Williams, F. K. (2005). Inside the one-room schoolhouse: A look at nongraded classrooms from the inside out. National forum of applied educational research Journal, Vol.18(3), (pp. 2).

Winthrop, R., \& McGivney, E. (2015). Why wait 100 years? Bridging the gap in global education. Brookings.

World Bank, (2018). World Bank Data: Pakistan GDP, GNI, poverty line headcount. Retrieved from https://data.worldbank.org/country/pakistan.

World Literacy Foundation. (2012). The Economic \& Social Cost of Illiteracy. A Snapshot of Illiteracy and Its Causes in the UK and A Global Context. Retrieved from https://worldliteracyfoundation.org/wpcontent/uploads/2015/02/WLF-FINAL-ECONOMICREPORT.pdf.

Zancanaro, A., Todesco, J. L., \& Ramos, F. (2015). A Bibliometric Mapping of Open Educational Resources. International Review of Research in Open and Distance Learning, Vol. 16(1) 